\title{
Breast Cancer cM0 TNM Finding v7
}

National Cancer Institute

\section{Source}

National Cancer Institute. Breast Cancer CMO TNM Finding v7. NCI Thesaurus. Code C88373.

Breast cancer in which there is no clinical or radiographic evidence of distant metastases.

(from AJCC 7th Ed.) 